To Maega $\mid$ Jurnal Pengabdian Masyarakat

Oktober 2021, Vol.4, No.3, hal, 351-362

$\operatorname{ISSN}(P): 2622-6332 ; \operatorname{ISSN}(E): 2622-6340$

http://www.ojs.unanda.ac.id/index.php/tomaega

\title{
Pengaruh Pestisida Alami Untuk Membasmi Hama Pada Tanaman Cabai di Rumah Petani Karangjati
}

\author{
Tahlily Zakiyah Nur' ${ }^{1}$ Asep Amaludin ${ }^{2}$ \\ ${ }^{1}$ Tadris Matematika, Fakultas Tarbiyah Dan IImu Keguruan, Institut Agama Islam Negeri \\ Purwokerto \\ ${ }^{2}$ Dosen, Fakultas Dakwah, Institut Agama Islam Negeri Purwokerto \\ Email:tahlilyzakiyah@gmail.com ${ }^{1}$, Asep@iainpurwokerto.ac.id ${ }^{2}$ \\ Article History: \\ Received: 07-09-2021; Received in Revised: 02-10-2021; Accepted: 14-10-2021 \\ DOI: http://dx.doi.org/10.35914/tomaega.v4i3.869
}

\begin{abstract}
Abstrak
Tanaman cabai merupakan tanaman yang banyak dijumpai di Indonesia. Petani melakukan budidaya tanaman cabai karena minat dari masyarakat akan cabai sangat tinggi. Namun petani selalu dihadapkan dengan permasalahan hama yang sering menyerang tanaman cabainya. Kebanyakan petani menggunakan pestisida kimia untuk memberantas hama pada tanamannya. Memang cepat dalam memberantas hamanya, namun kurang baik dalam segi lingkungan dan kesehatan manusia. Untuk itu, penulis akan memberikan alternatif untuk memberantas hama yang ada ditanaman tanpa adanya efek samping baik tanaman itu sendiri maupun ekosistem disekitarnya. Metode yang digunakan dalam kegiatan pengabdian masyarakat ini yaitu observasi dan wawancara. Pembuatan pestisida alami ini menjadi salah satu alternatif karena ramah lingkungan dan aman untuk kesehatan manusia. Pestisida alami ini terbuat dari kotoran kambing, dan rempah-rempah yang sering digunakan ibu dalam memasak. Pestisida ini disosialisasikan kepada masyarakat khususnya yang bergerak di bidang pertanian. Untuk mengetahui efektif tidaknya penggunaan pestisida alami dalam memberantas hama dilakukan dengan pengamatan setelah penyemprotan pestisida alami secara rutin untuk tanaman cabai yang terserang hama. Sehingga dari pengamatan ini didapati penggunaan pestisida dari kegiatan pembuatan pestisida alami, penyemprotan pestisidanya ke tanaman yang terdapat hama, penyemprotan dilakukan sehingga didapati dari hasil pengamatannya pestisida ini cukup efektif dalam memberantas hama yang terdapat di tanaman cabai. Dari hasil pengamatan didapati penyemprotan pestisida alami secara rutin dapat meminimalisir penyebaran hama ditanaman.
\end{abstract}

Kata Kunci: Pestisida Alami, Hama, Tanaman Cabai.

\begin{abstract}
Chili plants are plants that are often found in Indonesia. Farmers cultivate chili plants because the public's interest in chili is very high. However, farmers are always faced with the problem of pests that often attack their chili plants. Most farmers use chemical pesticides to eradicate pests on their crops. It is fast in eradicating the pests, but it is not good in terms of the environment and human health. For this reason, the author will provide an alternative to eradicate pests that exist in plants without any side effects, both the plant itself and the surrounding ecosystem. The method used in this community service activity is observation and interviews. Making natural pesticides is an alternative because it is environmentally friendly and safe for human health. This natural pesticide is made from goat dung, and spices that mothers often use in cooking. These pesticides are socialized to the public, especially those engaged in agriculture. To find out whether the
\end{abstract}


use of natural pesticides is effective in eradicating pests is carried out by observing after spraying natural pesticides on a regular basis for chili plants that are attacked by pests. So from this observation it was found that the use of pesticides from the activities of making natural pesticides, spraying was carried out so that it was found from the observations that these pesticides were quite effective in eradicating pests found in chili plants. From the observations, it was found that regular natural pesticide spraying can minimize the spread of pests on plants.

Key Word: Natural pesticides, pests, chili plants.

\section{Pendahuluan}

Tanaman cabai merupakan tanaman yang sering dibudidaya oleh petani. Budidaya tanaman cabai merupakan kegiatan usaha tani yang menjanjikan keuntungan yang menarik. Di Indonesia permintaan cabai dipasaran cukup tinggi. Untuk memenuhi permintaan cabai, maka petani cabai banyak dijumpai di Indonesia. Tanaman cabai rawit berasal dari Amerika Latin terletak digaris lintang 0-30 LU dan 0-30 ${ }^{\circ} \mathrm{LS}$, mempunyai nama Ilmiah Capsicum frutescens L (B.Ciota, 1986).

Tanaman cabe merupakan tanaman setahun yang berbentuk perdu, banyak dibutuhkan manusia sebagai bahan masak, karena sifat pedasnya yang berasal dari minyak atsiri. Dalam klasifikasi, tanaman cabe termasuk dalam kelas Angiosperma, subkelas Dicotyledonae, Ordo Polimoniales, famili Solaceae, genus Capsicus dan spesies Capsicum annum L (Edy dkk, 2012).

Tanaman cabai di Indonesia dengan mudahnya untuk dibudidaya. Namun tanaman cabai ini sering dihadapkan pada berbagai masalah, salah satunya yaitu hama. Hama ini merupakan salah satu faktor penghambat kelancaran dalam budidaya tanaman cabai. Hama adalah binatang perusak tanaman hasil budidaya petani yang berguna untuk mensejahterakan manusia. Hama tanaman merupakan makhluk hidup pengganggu berupa hewan yang umumnya dapat dilihat dengan mata telanjang (Djojosumarto, 2008). Hama yang bersarang ditanaman cabai tidak mungkin ada kalau tidak ada penyebabnya. Penyebab adanya hama ditanaman antara lain perubahan tempat, perubahan lingkungan, serta aplikasi pestisida yang tidak bijaksana (Rahmawati, 2012).

Tanaman cabai selalu dihadapkan dengan permasalahan adanya hama. Hama yang dapat menyerang tanaman cabai antara lain Kumbang Epilachna, Hama Aphis, Ulat Grayak Tungau, Thrips, lalat buah, kutu putih. Dari beberapa hama yang menyerang tanaman cabe seringkali menjumpai kutu putih yang hinggap didaun tanaman (Pracaya, 2008).

Dalam memberantas hama pada tanaman cabai sering kali petani mengandalkan pestisida kimia. Memang prosesnya cepat namun efek sampingnya dapat menyebabkan kerusakan lingkungan. Selain itu juga kurang baik bagi kesehatan manusia. Untuk dapat mengendalikan hama yang ramah lingkungan dan aman untuk kesehatan maka sebagai alternatifnya dengan penggunaan pestisida 
alami yang terbuat dari bahan-bahan alami untuk memberantas hama tanaman khususnya tanaman cabai. Pestisida alami adalah pestisida yang terbuat dari bahan alami, dan mudah didapatkan. Pestisida alami dapat berguna untuk mengendalikan hama dan penyakit tanpa mengganggu kelestarian lingkungan. Namun untuk pestisida alami ini, membutuhkan waktu yang tidak instan seperti penggunaan pestisida kimia.

Petani cabai didesa Karangjati, mempunyai masalah tentang tanaman cabainya yang terserang hama, tetapi kebanyakan dari mereka menggunakan pestisida yang cepat penanganannya tetapi kurang baik bagi lingkungan sekitar bahkan kesehatan manusia itu sendiri. Kurangnya edukasi terkait budidaya tanaman cabai ini, sehingga petani cabai kebanyakan menggunakan pestisisda kimia untuk menanggulangi adanya serangan hama pada tanamannya.

Kita melihat dari permasalahan yang dialami petani tentang pemberantasan hama pada tanaman cabai ini, adanya ketergantungan penggunaan pestisida kimia dengan dialihkan kepada penggunaan pestisida alami yang aman bagi lingkungan dan kesehatan manusia. Pembuatan pestisida alami ini akan melibatkan petani cabai agar nantinya dapat membuat pestisida alami sendiri. Bahan- bahan yang diperlukan untuk pembuatan pestisida alami ini mudah didapatkan dan biaya yang dikeluarkan sedikit.

Berdasarkan uraian permasalahan diatas, penulis mempunyai solusi dari adanya pemakaian pestisida kimia yang sering digunakan petani dalam memberantas hama dialihkan dengan pengenalan pestisida alami dilingkungan petani cabai. Dengan memperkenalkan pestisida alami kepada petani. Perkenalan pestisida alami ini dibarengi dengan pembuatan pestisida alami yang ramah lingkungan atau lebih menyelamatkan ekosistem lingkungan yang berada disekitar tanaman yang terserang hama. Pestisida alami ini tidak berdampak negatif bagi lingkungan dan kesehatan manusia. Selain itu, biaya yang dikeluarkan untuk pembuatan pestisida alami ini lebih murah dibandingkan untuk membeli pestisida kimia. Pestisida alami ini akan digunakan untuk memberantas hama pada tanaman cabai.

\section{Metode}

Kegiatan pengabdian masyarakat ini dilaksanakan di Desa Karangjati pada tanggal 14 Agustus-25 Agustus 2021. Petani yang mengikuti kegiatan pembuatan pestisida alami sekaligus penyemprotan pestisida alami guna memberantas hama berjumlah 3 orang. Untuk metode pelaksanaan kegiatan sebagai berikut:

\section{A. Rancangan Kegiatan}

Sebelum melaksanakan penyemprotan pestisida alami pada tanaman cabai yang terserang hama, berikut rencana kegiatannya:

- Membuat pestisida alami dari kotoran kambing, dan bumbu dapur. 
[ 354 ] Tahlily Zakiyah Nur, dkk / To Maega : Jurnal Pengabdian Masyarakat, Vol.4; No.3; Oktober 2021

- Melakukan pengamatan adanya hama pada tanaman cabai sebelum dilakukan penyemprotan.

- Mengaplikasikan pestisida alami ke tanaman cabai yang terserang hama.

- Melakukan penyemprotan pestisida alami secara rutin agar hama tidak nyaman di tanaman cabai.

- Melakukan pengamatan pada tanaman cabai yang sudah dilakukan penyemprotan.

- Melakukan wawancara dengan salah satu petani cabai untuk mengetahui keefektifan dari penggunaan pestisida alami.

\section{B. Lokasi Kegiatan}

Untuk pembuatan dan penyemprotan pestisida alami pada tanaman cabai dilaksanakan dirumah bapak ilham. Lokasinya berada di RT 002/010 Karangjati, Sampang.

\section{Partisipan Kegiatan}

Partisipan kegiatan pembuatan dan penyemprotan pestisida alami yaitu petani cabai yang ada didesa karangjati, khususnya didusun randegan dan mahasiswa KKN.

\section{Bahan dan Alat}

Bahan dan alat yang digunakan untuk pembuatan pestisida alami dalam mengatasi hama pada tanaman cabai yaitu kotoran kambing, lengkuas, daun salam, gula jawa, kayu manis, air kelapa, air secukupnya, ember, spatula, plastic penutup ember. Rincian banyaknya penggunaan bahan tersebut antara lain

1. Kotoran kambing 1 kantong plastik sedang

2. Lengkuas $1 / 4 \mathrm{~kg}$

3. Daun salam 10 lembar

4. Gula jawa 4 butir

5. Kayu manis secukupnya

6. Air kelapa (1 buah kelapa)

7. Air secukupnya.

Untuk lengkuas digeprek terlebih dahulu bersama kayu manis. Gula jawa dipotong-potong hingga hancur, lalu untuk daun salam cukup diremas sampai menjadi butiran kecil.

\section{E. Metode Pelaksanaan Kegiatan}

Kegiatan dilaksanakan dengan memberikan pelatihan kepada petani cabai untuk pembuatan pestisida alami dari bahan baku kotoran kambing dan bumbu dapur masak. Setelah itu, pengaplikasian pestisida alami yang sudah dibuat untuk tanaman cabai yang terserang hama. Dari pelaksanaan pembuatan dan penyemprotan pestisida alami dari bahan baku kotoran kambing dan bumbu dapur masak dapat mengetahui keefektifan dari penggunaan pestisida. Pestisida alami selain digunakan untuk obat dalam pemberantasan hama juga dapat 
digunakan sebagai pupuk untuk menutrisi tanah sebelum digunakan sebagai media tanam oleh petani.

\section{F. Metode Pengumpulan Data}

Pengumpulan data yaitu serangkaian kegiatan yang dapat digunakan untuk penunjang adanya suatu penelitian. Berdasarkan penelitian ini, data dikumpulkan dengan melakukan observasi dan wawancara. Melakukan pengamatan secara langsung pada tanaman cabai yang terserang hama. pengamatan dilaksanakan sebelum dilaksanakan penyemprotan dan sudah dilakukan penyemprotan. Tujuannya untuk mengetahui perubahan yang terjadi pada hama yang ada ditanaman cabai. Dari pengamatan tersebut, nantinya kita akan mengetahui pestisida alami yang sudah dibuat oleh petani cabai dan mahasiswa KKN, sudah efektif diterapkan untuk pemberantasan hama pada tanaman cabai atau belum.

Selain melakukan pengamatan pada tanaman cabai yang terserang hama, pengumpulan data juga dilakukan dengan mewawancarai salah satu petani cabai yang ada di Desa Karangjati terkait penggunaan pestisida alami yang dibuat untuk memberantas atau lebih tepatnya mengusir hama pada tanaman cabai. Wawancara tersebut meliputi efektif tidaknya penerapan pestisida alami yang dibuat, kemudian respon yang diberikan petani ketika diperkenalkan dengan pestisida alami yang ramah lingkungan, baik bagi kesehatan manusia dan biaya yang dikeluarkan sedikit.

Data dari hasil observasi dan wawancara ini sebagai penunjang dalam kegiatan pengabdian masyarakat yang dilakukan bersama petani cabai.

\section{Hasil dan Pembahasan}

\section{A. Pembuatan Pestisida Alami}

Pestisida alami adalah pestisida yang terbuat dari bahan alami dan tentunya aman digunakan untuk pemberantasan hama yang ada ditanaman. Petani cabai sering dihadapkan dengan masalah terkait hama yang sering menyerang tanamannya. Petani sering menggunakan pestisida kimia untuk mengatasi masalah tersebut. Padahal petani tersebut sudah mengetahui bahaya yang ditimbulkan dari adanya penggunaan pestisida kimia. Apabila pemakaian pestisida kimia tersebut tidak sesuai dengan anjuran yang diberikan, maka akan berdampak buruk bagi ekosistem lingkungan disekitarnya. Selain itu juga berdampak buruk bagi kesehatan manusia yang mengonsumsinya. Penggunaan pestisida kimia ini, menurut petani sebagai satu-satunya alternatif untuk pemberatasan hama. Petani yang kurang mengetahui adanya efek samping yang ditimbulkan dengan penggunaan pestisida kimia ini, sehingga pestisida kimia ini digunakan untuk mengatasi masalah hama.

Dari minimnya pengetahuan petani akan pestisida alami ini, maka penulis mengadakan pelatihan pembuatan pestisida alami yang ramah lingkungan, baik 
bagi kesehatan, dan biaya yang dikeluarkan sedikit. Pelatihan pembuatan pestisida alami ini dilaksanakan pada tanggal 14 Agustus 2021dirumah masyarakat yang ditempati mahasiswa KKN pada pukul 09.00 WIB. Pembuatan pestisida alami ini diikuti oleh petani cabai dan mahasiswa KKN. Pemberian informasi terkait apa saja yang bahan yang digunakan untuk pembuatan pestisida alami ini.

Pembuatan pestisida alami dapat terlaksana dengan baik. Petani dapat mengikuti serangkaian tahapan yang dilakukan dalam pembuatan pestisida alami. Dimulai dari mempersiapkan bahan-bahan yang diperlukan, kemudian proses pembuatan pestisida alami dapat diikuti oleh petani cabai desa Karangjati dan mahasiswa KKN. Dengan adanya kegiatan ini, petani dapat mengikuti serangkaian pembuatan pestisida alami yang bertujuan untuk mengenalkan pestisida alami yang dapat memberantas hama dengan mempertimbangkan pestisida alami ini ramah lingkungan, dan aman bagi kesehatan lingkungan. Selain itu, bahan baku pembuatan pestisida alami ini mudah didapatkan, dan biaya pembuatannya tidak mahal.

Sebelum pembuatan pestisida alami ini dilaksanakan, mahasiswa KKN memberikan materi tentang tata cara pembuatan pestisida alami kepada petani yang mengikuti kegiatan ini.

Adapun langkah-langkah pembuatan pestisida alami, antara lain:

1. Masukkan kotoran kambing kedalam ember.

2. Setelah itu masukkan semua bumbu dapur (lengkuas, daun salam, kayu manis) ke ember.

3. Masukkan gula jawa yang sudah dipotong-potong hingga hancur.

4. Masukkan air kelapa.

5. Masukkan air secukupnya.

6. Selanjutnya, aduk semua bahan yang sudah dimasukkan ke ember.

7. Langkah terakhir tutup ember tersebut dengan plastik.

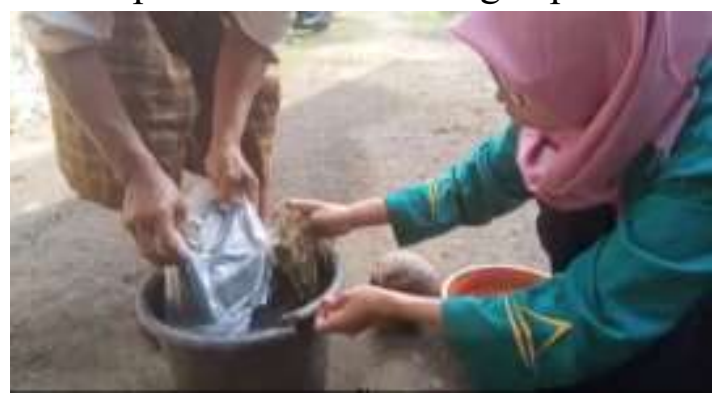

Gambar 1. Pembuatan Pestisida Alami

Pengenalan pestisida alami untuk petani ini sangat diperlukan, agar dalam pemberantasan hama tidak selalu bertumpuan pada pestisida kimianya. Pestisida kimia ini sangat berbahaya, manakala tidak digunakan sesuai takarannya. Pestisida alami ini, selain dapat memberantas hama juga dapat dimanfaatkan untuk penyuburan tanah sebagai tempat bercocok tanam. 
[ 357 ] Tahlily Zakiyah Nur, dkk / To Maega : Jurnal Pengabdian Masyarakat, Vol.4; No.3; Oktober 2021

\section{B. Penyemprotan Pestisida Alami}

Penyemprotan yaitu suatu kegiatan yang dilakukan oleh petani. Penyemprotan pestisida alami adalah kegiatan yang paling inti dalam pemberantasan hama. apabila penyemprotan dapat dilaksakan dan dilakukan secara rutin maka hama akan cepat teratasi. Hama tidak akan menetap ditanaman cabai dalam kurun waktu yang lama. Penulis melaksanakan penyemprotan pestisida alami ini sebanyak lima kali. Dan sebelum penyemprotan pestisida alami dilakukan pengamatan pada tanaman cabai yang terserang hama. Kondisi tanaman cabai tersebut termasuk parah atau tidak. Berdasarkan pengamatan, didapati tanaman cabai yang terserang hama tergolong parah. Tanaman cabai dihinggapi oleh kutu putuh dan daun cabai itu menggulung disertai dengan daun berwarna kuning dibagian pangkal daunnya.

Dalam mengatasi permasalahan hama ini, cara yang ditempuh yaitu dilakukan penyemprotan secara rutin yaitu dua hari sekali untuk mengetahui efektifnya penggunaan pestisida alami untuk memberantas hama pada tanaman cabai. Penyemprotan secara rutin ini, nantinya dapat mengatasi masalah hama yang sering hinggap ditanaman cabai. Penyemprotan pestisida alami tidak memiliki efek samping yang dapat membahayakan ekosistem lingkungan sekitar dan bahkan tida mengganggu kesehatan manusia. Pestisida alami sangat aman digunakan.

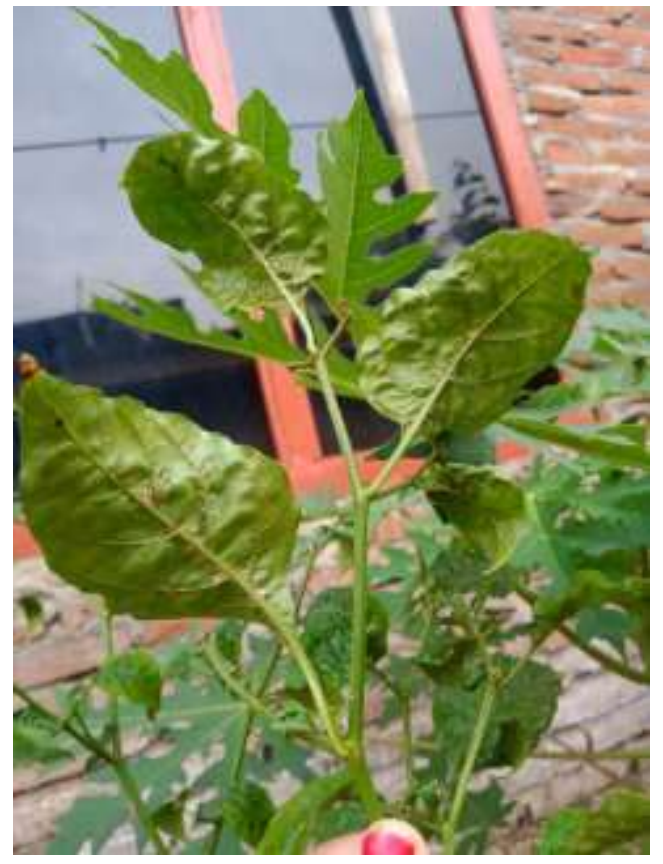

Gambar 2. Sebelum penyemprotan pestisida alami

Penyemprotan dilakukan sebanyak lima kali untuk mengetahui perkembangan pemberantasan hama pada tanaman cabai. Penyemprotan ini bertujuan untuk membuat hama tidak nyaman ditanaman cabai dan segera menghilang dari tanaman cabai. Penyemprotan pertama dilakukan pada tanggal 21 Agustus 2021 pada pukul 06.30 WIB. Pada penyemprotan pertama hasil yang (https://creativecommons.org/licenses/by-sa/4.0/). 
dicapai yaitu cukup baik. Hama yang ada ditanaman cabai sudah mulai berkurang. Hama tersebut sudah berkurang dari pengamatan sebelum penyemprotan pestisida alami dilaksanakan.

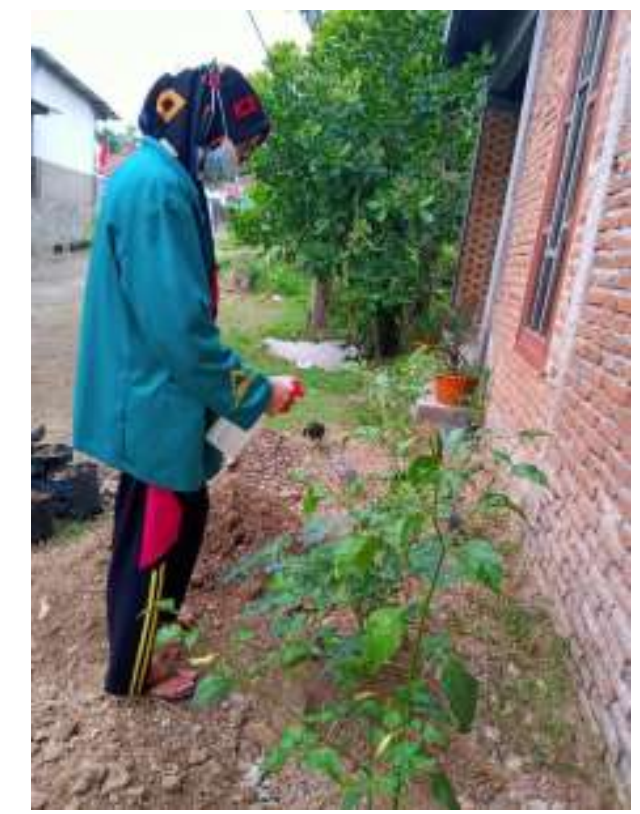

Gambar 3. Pelaksanaan Penyemprotan

Penyemprotan pestisida alami yang kedua dilaksankan pada tanggal 23 Agustus 2021 pada pukul 06.30 WIB, hasil yang dicapai yaitu perkembangan hama sudah berkurang dari sebelum dilakukan penyemprotan. Hama sudah berkurang $20 \%$ dari sebelumnya. Untuk penyemprotan ketiga yang dilaksanakan pada tanggal 25 Agustus 2021, hasil yang dicapai dengan dilakukannya penyemprotan yaitu hama sudah berkurang kembali dari sebelumnya. Selain itu daun tanaman cabai sudah mulai bagus tidak menggulung lagi. Penyemprotan keempat dengan menggunakan pestisida alami yang dilaksakan pada tanggal 27 Agustus 2021 ini menghasilkan tanamaan cabai sudah lebih baik dari penyemprotan pertama. Hama semakin berkurang, tanaman sudah mulai segar kembali. Untuk penyemprotan kelima dilaksanakan pada tanggal 29 Agustus 2021 hasil yang dicapai dengan adanya penyemprotan pestisida alami yang kelima yaitu hama sudah tidak ada lagi pada tanaman cabai dan tanaman cabai sudah sehat kembali.

Penyemprotan pestisida ini dilakukan secara rutin karena untuk hasil yang didapatkan tidak bisa instan seperti kinerja dari pestisida kimia yang sering digunakan prtani cabai. Namun, penggunaan pestisida alami ini lebih ramah lingkungan, biaya yang dikeluarkan sedikit alias murah, dan baik bagi kesehatan manusia. 


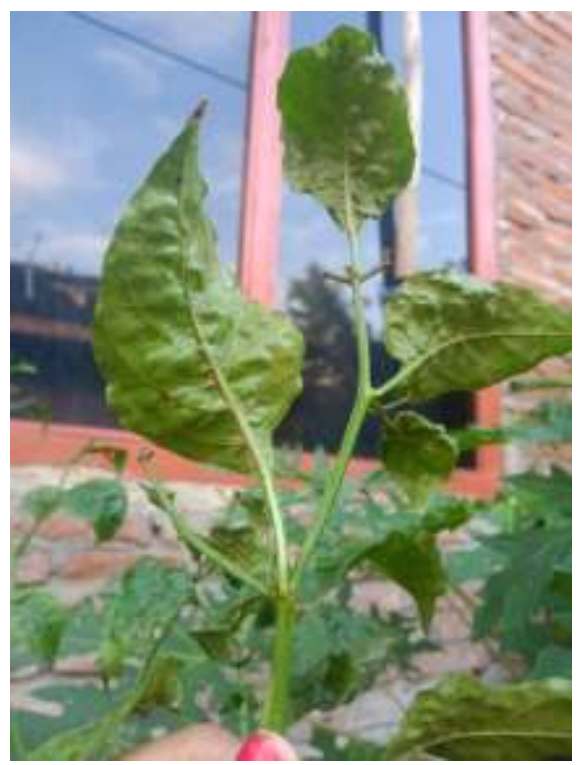

Gambar 4. Setelah Penyemprotan

Pembuatan sekaligus penerapan pestisida alami untuk memberantas hama pada tanaman cabai berhasil diterapkan. Dampak yang ditimbulkan dari penggunaan pestisida ini dapat mengusir hama yang ada ditanaman cabai. Hama dapat diatasi dengan penyemprotan pestisida alami yang terbuat dari bahan kotoran kambing dan bumbu dapur untuk memasak.

Berdasarkan wawancara dengan salah satu petani cabai, penerapan pestisida alami sudah baik, hasil yang didapatkan dari penggunaan pestisida alami dapat memberantas hama yang terdapat pada tanaman cabai. Selain itu, pestisida ini mudah dibuat oleh petani karena bahan yang diperlukan mudah didapatkan, dan biaya yang dikeluarkan sedikit.

Pemberantasan hama tanaman cabai menggunakan pestisida alami cukup efektif. Karena dengan percobaan penyemprotan secara rutin ternyata hama tanaman cabai sudah tidak ada lagi. Petani dapat memanfaatkan pestisida ini sebagai salah satu solusi apabila mendapati hama yang menyerang tanaman cabainya kembali. Pestisida ini nantinya akan dikenalkan lagi untuk para petani yang masih minim akan pengetahuan untuk pemberantasan hama tanaman cabai. Petani dapat memanfaatkan pestisida ini untuk menanggulangi adanya hama yang kembali menyerang tanaman cabainya.

Penggunaan pestisida alami yang ramah lingkungan, biaya murah, dan baik kesehatan manusia sangat diperlukan oleh para petani. Tidak menimbulkan efek samping dari adanya penggunaan pestisida ini sangat dibutuhkan oleh petani dalam memberantas hama yang ada ditanamannya.

Pemanfaatan pestisida alami ini selain sebagai pemberantasan hama juga dapat digunakan sebagai pupuk bagi tanah. Jadi sebelum dilaksanakan penanaman suatu tanaman, tanah bisa mendapatkan nutrisi dari adanya pestisida alami ini. Cara penggunaannya dengan menyemprotkan pestisida alami ini pada tanah yang akan digunakan sebagai media tanam. Pestisida alami ini bagus (O) To Maega / Jurnal Pengabdian Masyarakat. This is an open access article under the CC BY-SA 4.0 license (https://creativecommons.org/licenses/by-sa/4.0/). 
[ 360 ] Tahlily Zakiyah Nur, dkk / To Maega : Jurnal Pengabdian Masyarakat, Vol.4; No.3; Oktober 2021

diterapkan bukan hanya untuk memberantas hama saja, tetapi dapat dimanfaatkan untuk kesuburan tanah dan juga dapat menutrisi tanaman.

Tabel 1. Pestisida Alami

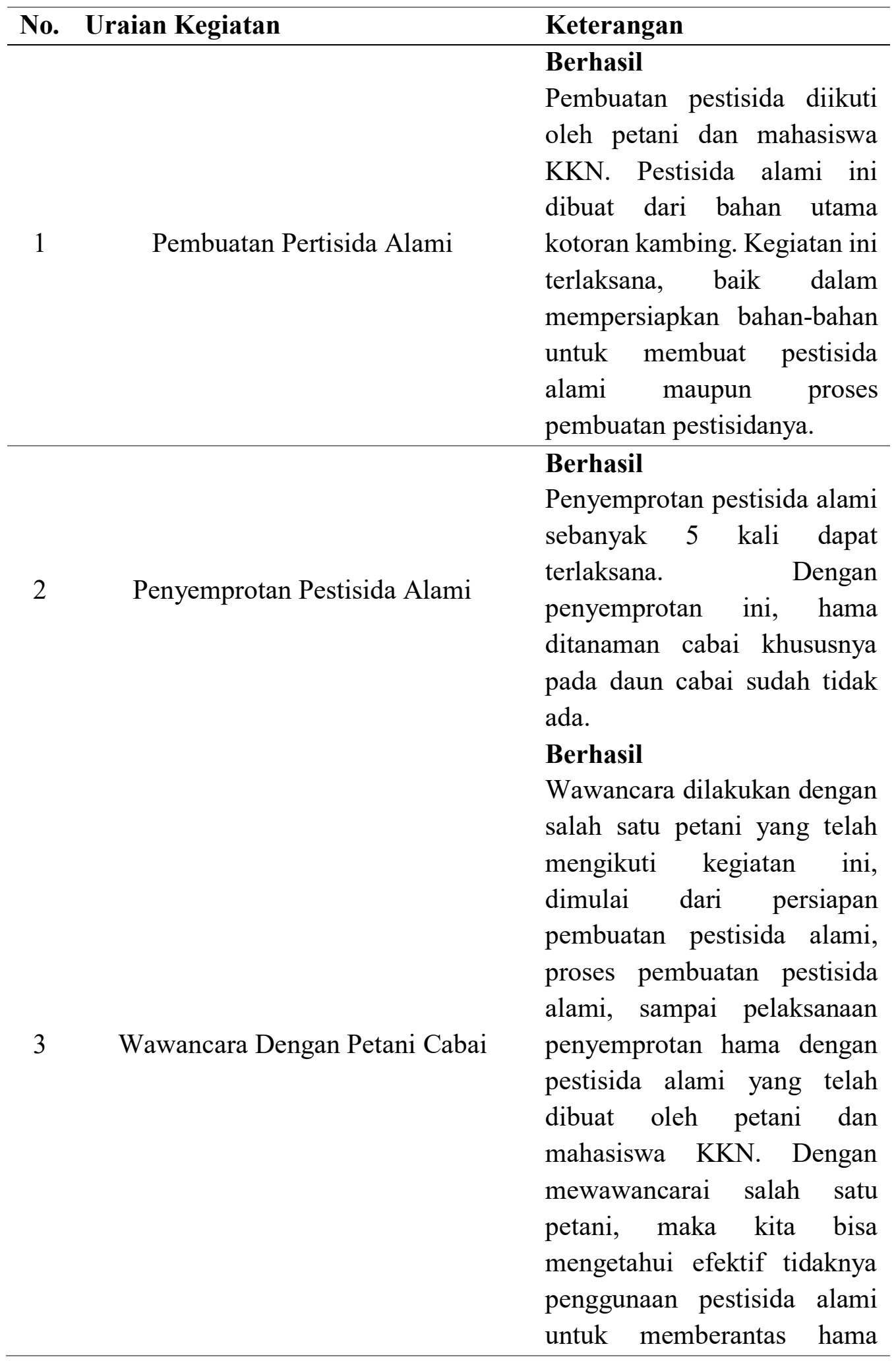


terutama hama pada tanaman

cabai.

\section{Kesimpulan}

Pestisida alami dapat digunakan untuk memberantas hama pada tanaman cabai. Pestisida ini berdampak baik bagi lingkungan dan kesehatan manusia. Petani dapat membuat pestisida alami sendiri, karena bahannya yang mudah didapat dan murah. Sebelum melaksanakan penyemprotan, petani cabai dan mahasiswa KKN melaksanakan kegiatan pembuatan pestisida alami yang dapat dimanfaatkan untuk memberantasan hama. setelah pembuatan pestisida selesai, setelah itu dilaksakan penyemprotan hama pada tanaman cabai dengan menggunakan pestisida alami yang telah dibuat oleh petani cabai dan mahasiswa KKN. Penyemprotan dengan menggunakan pestisida alami dapat jadikan salah satu alternatif untuk memberantas hama. Petani dapat memanfaatkannya, karena dari segi keamanan pestisida alami ini sangat cocok untuk membasmi hama yang ada di tanaman.

Setelah mengetahui adanya pestisida yang cocok untuk memberantas hama tanpa mempertimbangkan efek samping yang ditimbulkan, maka kedepannya penggunaan pestisida kimianya dikurangi bahkan yang lebih baik yaitu dengan memanfaatkan pestisida alaminya saja dalam memberantas hama yang ada ditanaman khusunya tanaman cabai. Pestisida alami ini cukup efektif dalam pemberantasana hama yang ada di tanaman cabai. Hasil yang dicapai tidak instan. Diperlukan penyemprotan secara rutin agar hama dapat diberantas. Pestisida alami ini aman bagi ekosistem lingkungan yang ada disekitar tanaman juga aman bagi kesehatan manusia. Berbeda dengan pestisida kimia, cara kerjanya instan. Namun dampak yang ditimbulkan dapat merusak ekosistem lingkungan disekitar tanaman bahkan dapat mengganggu kesehatan manusia. Harapannya dari kegiatan yang semacam ini akan terus ada sehingga petani mempunyai berbagai macam alternatif yang dapat ditempuh untuk memberantas hama tanaman.

\section{Ucapan Terimakasih}

Dalam kesempatan kali ini, saya ucapkan terimakasih kepada: 1. Dosen Pembimbing Lapangan, Bapak Asep Amaludin, S.Pd., M.Si. yang telah membimbing dalam pembuatan jurnal ini. 2. Orang tua, Ibu Siti Fatimah, S.Pd.AUD. dan Bapak Ilham Suhudi serta keluarga yang selalu menjadi penyemangat terbaik. 3. Pihak yang sudah ikut berkontribusi dalam pembuatan jurnal pengabdian masyarakat terutama pihak masyarakat Desa Karangjati yang sudah ikut dalam menyukseskan pembuatan jurnal ini. Penulis menyadari bahwa masih banyak kekurangan dalam pembuatan jurnal ini, maka dari itu penulis memohon maaf sebesar-besarnya. 
[ 362 ] Tahlily Zakiyah Nur, dkk / To Maega : Jurnal Pengabdian Masyarakat, Vol.4; No.3; Oktober 2021

\section{Daftar Pustaka}

Adriyani, R. (2006). Usaha pengendalian pencemaran lingkungan akibat penggunaan pestisida pertanian. Jurnal Kesehatan Lingkungan, 3(1).

Bahar,Y.H., Andayani, A. (2009). Pedoman Umum Standar Operasional Prodesedur (SOP): Budidaya Cabai Rawit. Jakarta: Departemen Pertanian Direktorat Henderal Hortikultura Direktorat Budidaya Tanaman Sayuran Dan Biofarmaka.

B.Ciota. (1986). Bertanam Cabai Besar. Bandung: Bina Cipta Bandung.

Djojosumarto, P., (2008). Teknik Aplikasi Pestisida Pertanian, Kanisius, Yogyakarta.

Edy, H.W, Nano S., Akbar A.D., Agus, W. (2012). Pertanian Alami: Bio-starter, Composting dan Pestisida Alami. Bogor: Yayasan Pendidikan Konservasi (YAPEKA).

Fatma S.H., Yusni A., Iskandar S.H, Abubakar (2018). Penyuluhan Penggunaan Pestisida Alami Bagi Kelompok Tani Di Desa Hutan Male Kec Puncak Sorik Marapi Mandailing Natal. MARTABE: Jurnal Pengabdian Masyarakat.

Hariyadi, H., Winarti, S., \& Basuki, B. (2021). Kompos dan pupuk organik cair untuk pertumbuhan dan hasil cabai rawit (Capsicum frutescens) di tanah gambut. Journal of Environment and Management, 2(1), 61-70.

Kardinan, A. (2011). Penggunaan pestisida nabati sebagai kearifan lokal dalam pengendalian hama tanaman menuju sistem pertanian organik. Pengembangan Inovasi Pertanian, 4(4), 262-278.

Pamungkas, P. B., \& Ardiyanta, A. (2020). Meningkatkan Pemahaman akan Pengendalian OPT Bawang Putih pada Anggota Kelompok Tani Ngudi Rahayu. To Maega: Jurnal Pengabdian Masyarakat, 3(2), 104-110.

Purnama, H., Hidayati, N., \& Setyowati, E. (2015). PENGEMBANGAN PRODUKSI PESTISIDA ALAMI DARI Beauveria bassianaDAN Trichoderma sp. MENUJU PERTANIAN ORGANIK. Warta LPM, 18(1), $1-9$.

Pracaya. (2008). Pengendalian Hama dan Penyakit Tanaman Secara Organik, Yogyakarta: Kanisius.

Presson, J., Gelyaman, G. D., Kedang, Y. I., Kolo, S. M. D., Seran, R., Edi, E., \& Kolo, M. M. (2019). Potensi Ekstrak Tanaman Sebagai Pestisida Alami Di Desa Salu Kecamatan Miomafo Barat Kabupaten TTU. Bakti Cendana, 2(2), 71-75.

Rahmawati. (2012). Cepat dan tepat Berantas Hama dan Penyakit Tanaman. Yogyakarta: Pustaka Baru Press.

Santoso, E., \& Dono. (2013). Pelatihan Pembuatan Pestisida Alami untuk mengendalikan Hama dan Penyakit Tanaman Padi di Desa Tenjolaya dan Desa Sukamelang, Kecamatan Kosamalang, Kabupaten Subang. (2)2,139145.

Tri, K., Rini, I., \& Rina F. (2020). Sistem Pemberantasan Hama Tanaman Cabe. Seminar Nasional Inovasi Teknologi UN PGRI Kediri. 